Informatika i sistemy upravleniya. - 2017. - No. 1(51). - P. 45-52.

Efanov D.V. (TrES-4b@yandex.ru)

Emperor Alexander I St. Petersburg state transport university

\title{
ABOUT FEATURES OF PATTERN GENERATOR SYNTHESIS WITH WEIGHTED TRANSI- TIONS SUMMATION
}

Classical sum codes (Berger codes) and their modifications are often used when building reliable discrete systems and solving a task of technical diagnostics. The sum code of weighted transitions is one of such modifications. This article offers a method of generator synthesis (coder) of place value of its check vectors based on properties of sum codes with weighted transitions. We described a way of building generator that can control its technical condition and use self-dual Boolean functions.

Keywords: Berger code; code with summation of weighted transitions; generator; decomposition of functions by variables; multiplexer; self-dual function; self-dual function check.

DOI: 10.22250/isu.2017.51.45-52

For citation:

Efanov D.V. ABOUT FEATURES OF PATTERN GENERATOR SYNTHESIS WITH WEIGHTED TRANSITIONS SUMMATION // Informatika i sistemy upravleniya. - 2017. - No. 1(51). - P. 45-52. 